\title{
Contamination status and health risk assessment of trace elements in foodstuffs collected from the Buriganga River embankments, Dhaka, Bangladesh
}

\author{
Faysal Elahi Khan', Yeasmin Nahar Jolly²*, GM Rabiul Islam', Shirin Akhter ${ }^{2}$ and Jamiul Kabir ${ }^{2}$
}

\begin{abstract}
Background: Unsafe food consumption is a severe problem because of heavy metal contamination, which is caused by director indirect activities of industries. The present study was conducted to assess the risk of human health by Heavy metals ( $\mathrm{Cu}, \mathrm{Co}, \mathrm{Fe}, \mathrm{Zn}$ and $\mathrm{Mn}$ ) through the intake of vegetables and fishes obtained from the area adjacent to the Hazaribag tannery campus, Dhaka, Bangladesh.

Result: The trend of mean metal concentration in Buriganga river water was Fe $>\mathrm{Mn}>\mathrm{Zn}>\mathrm{Cu}>\mathrm{Co}$ and according to Department of Environment, Dhaka Bangladesh (DoE) (1999) the value of the above metals are within the permissible limit of irrigation water except Fe. An assessment of risk involved due to consumption of contaminated food also calculated. The trend of metals in vegetables was $\mathrm{Fe}>\mathrm{Mn}>\mathrm{Zn}>\mathrm{Cu}>\mathrm{Co}$ and in fishes the trend was $\mathrm{Fe}>\mathrm{Zn}>\mathrm{Mn}>\mathrm{Co}>\mathrm{Cu}$. Accumulation of trace elements in vegetables was lower than maximum tolerable levels proposed by FAO/WHO food standard programme (2001) with the exception of Fe and Co respectively. In fishes metal concentration was lower than safe limit set by WHO (1989) except Mn. The Metal Pollution Index (MPI) for all the foodstuffs showed a higher value, however the calculated Health Risk Index (HRI) indicated no risk to human health upon consumption of those foodstuffs.
\end{abstract}

Conclusion: The overall study suggests that foodstuff in the area were contaminated by the assayed metals and long-term consumption can cause potential health risks to consumers.

Keywords: Daily intake; Heavy metal; Health risk; Metal pollution index

\section{Background}

Rapid development, growing populations, as well as increasing urbanization and food demand in Southeast Asia combined with the use of polluted waters for pre-urban food constitute a potential food safety risk. The knowledge of dietary intake of essential and toxic elements in Southeast Asian countries such as Bangladesh is limited. The poisoning effects of heavy metals are due to their interference with normal body biochemistry in normal metabolic process (Okunola et al. 2011). Heavy metals are classified in two main categories i.e. essential and toxic heavy metals. Essential heavy metals $(\mathrm{Cu}, \mathrm{Co}, \mathrm{Zn}, \mathrm{Fe}, \mathrm{Ca}, \mathrm{Mg}$, Se, $\mathrm{Ni}$ and $\mathrm{Mn}$ ) are required in very trace quantities for the proper functioning of enzyme systems, hemoglobin

\footnotetext{
* Correspondence: jolly_tipu@yahoo.com

${ }^{2}$ Chemistry Division, Atomic Energy Centre, Dhaka, Bangladesh

Full list of author information is available at the end of the article
}

formation and vitamin synthesis in human but metabolic disturbances are encountered in case of excess of these essential metals (Hina et al. 2011). In recent time, the rapid and exponential industrial growth in Bangladesh caused increased production of waste, which witnessed in Hazaribag industrial area located towards southwestern Dhaka. In Hazaribag area, there are about 277 tannery industries, 15 dying, 3 salt industries, 1 pharmaceutical industry, 1 soap factory, 2 match factories and 2 lead-zinc industries. Buriganga River, which is the major sources of water supply for agricultural, livestock and fishing activities (Azom et al. 2012), is contaminated by the wastes discharged from these industries as it contains a bulk amount of liquid and solid wastes with substantial quantities of heavy metals: $\mathrm{Zn}, \mathrm{Cu}, \mathrm{Co}, \mathrm{Fe}, \mathrm{Mn}, \mathrm{Ca}, \mathrm{Ni}, \mathrm{Mg}$, Se etc. The contamination of river allows these pollutants to accumulate in common fish species by biomagnifications, which are used as local food sources (Azom et al. 2012). Long-term 
use of wastewater in irrigation affect food quality thus safety (Muchuweti et al. 2006 and Sharma et al. 2007). Plants growing in nearby zone of industrial areas display increased concentration of heavy metals serving in many cases as bio-monitors of pollution loads (Mingorance et al. 2007). Vegetables cultivated in soil polluted by toxic heavy metals due to industrial activities take up heavy metals and accumulated them in their edible and non-edible parts.

Heavy metal pollution is of significant ecological or environmental concern because they are not easily biodegradable or metabolized thus precipitating far-reaching effects on the biological system such as human, animals, plants and other soil biota (Yoon 2003). Food chain contamination is the major pathway of heavy metal exposure for humans (Khan et al. 2008). In the present study area there are more than 0.2 million people and 20,000 people are directly exposed to the hazards (Asaduzzaman et al. 2002) and rest of people are affected by Dietary intake which is the main route of exposure of heavy metals for most people (Tripathi et al. 1997). Thus, information about heavy metal concentration in food products and their dietary intake is very important for assessing their risk to human health (Zhuang et al. 2009). The present study aimed to assess the contamination status of trace elements in water, vegetables and fishes of the adjacent area of the Hazaribag and embank of Buriganga River, Dhaka. The concentrations of trace elements in water, vegetables and fishes were compared with the established safe limit and the value of intake metals in human diet was calculated to estimate the risk to human health.

\section{Methods}

\section{Study area}

The study was carried out in the cluster of tannery industries in the Hazaribagh area of southwestern Dhaka. It lies within longitude $90^{\circ} 22^{\prime}-90^{\circ} 22^{\prime} 48^{/ /} \mathrm{E}$ and latitude $23^{\circ} 43^{\prime} 34^{\prime \prime} 23^{\circ} 43^{\prime} 49^{\prime \prime} \mathrm{N}$ and located by the side of River Buriganga. Lot of industries suited in Hazaribag and most of them discharge their effluents without any prior treatment in the Buriganga River. Different kinds of vegetables such as Brinjal, Eggplants, Chili, Stem Amaranth, Radish, Spinach etc. are cultivated in the nearby land of these industries throughout the year. Beside, a variety of small fishes also cultured in the Buriganga River throughout the year. A map of the sampling site is shown in Figure 1.

\section{Collection and preparation of samples}

Water, vegetables viz., Stem Amaranth (Amaranthus lividus), Radish (Raphanus sativus), Spinach (Spinacia oleracea); fishes viz., Tatina (Cirrhinus reba), Spotted snakehead (Channa punctate), MozambiqueTalipia (Oreochromis mossambicus) were randomly collected in triplicate from different location of the study area during the period of February to March 2013. The samples were tagged and carried in the laboratory.

\section{Preparation of water sample}

For Energy Dispersive X-ray Fluorescence (EDXRF) measurement of elements, the preparation of water samples involved the absorption of a certain amount of the sample on weighed amount of dry analar grade Whatman cellulose powder. A volume of $500 \mathrm{ml}$ of each collected water sample filtered with Whatman 41 filter paper was taken in a clean weighed porcelain dish followed by addition of $4 \mathrm{gm}$ of cellulose powder and evaporated on water bath. The sample after evaporation to dry mass was further dried under IR lamp at about $70^{\circ} \mathrm{C}$ for two hours to remove the trace of moisture and weighed. For homogeneous mixing, the dry mass was then transferred to a carbide mortar and ground to fine powder using a pestle. The processed sample in a plastic vial with identification mark was preserved inside a desiccator.

\section{Preparation of plant and fish samples}

The plant samples were cut into suitable pieces with a stainless steel knife, washed first with tap water, and rinsed with deionized water three times. The inedible parts of all fish samples were removed with a stainless steel knife. The remaining edible part of the samples were washed with tap water and then rinsed with deionized water three times. All plant and fish samples were then taken on porcelain dishes separately. Each dish with the particular sample was marked by an identification number and placed in an oven at around $70^{\circ} \mathrm{C}$ for overnight drying which was continued until a constant weight was obtained. The dried mass of each sample was then transferred to a carbide mortar and ground to fine powder using a pestle and preserved in a plastic vial with identification mark inside a desiccator.

\section{Analysis of samples}

The Panalytical Epsilon 5 Energy Dispersive X-ray Fluorescence (EDXRF) (model: Epsilon 5, made in Netherland) was used as major analytical technique for carrying out elemental analysis in the samples. For irradiation of the sample with X-ray beam $2 \mathrm{~g}$ of each powdered material was pressed into a pellet of $25 \mathrm{~mm}$ diameter with a pellet maker (CARVER, model: 38894NE1, U.S.A.) and loaded into the X-ray excitation chamber with the help of automatic sample changer system. The irradiation of all real samples was performed by assigning a time-based programme, controlled by a software package provided with the system. The standard materials were also irradiated under similar experimental conditions for construction of the calibration curves for quantitative elemental determination in the respective 


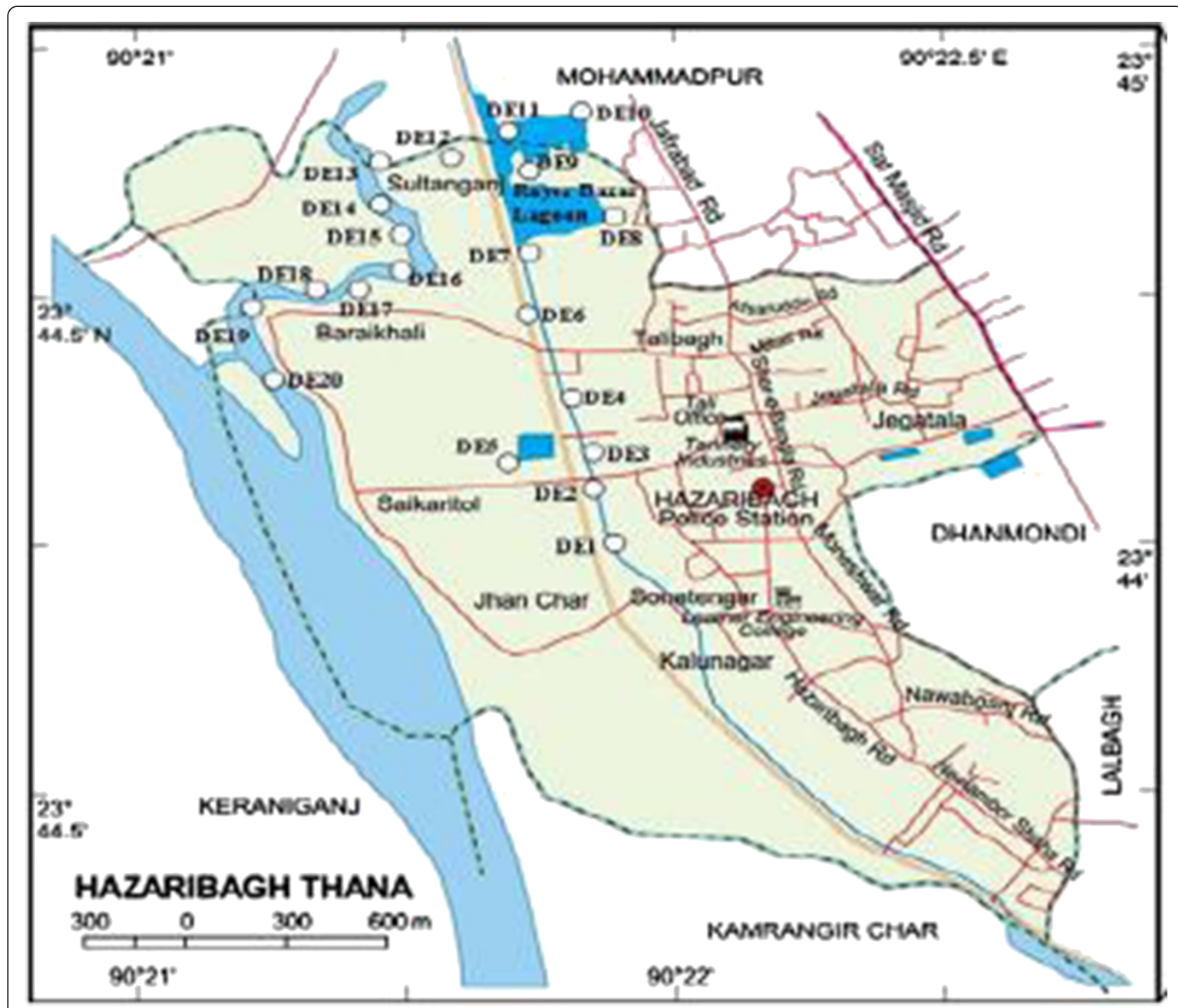

Figure 1 Map of the Sapling Site (Hazaribag), showing the sampling point by DE1, DE2....DE20.

samples. The generated X-ray spectra of the materials were stored into the computer. The X-ray intensities of the elements in sample spectrum were calculated using the system software by integration of area of the respective $\mathrm{X}$-ray peak areas using peak fitting deconvolution software.

\section{Concentration calibration and method validation}

A direct comparison method based on EDXRF technique was used for elemental concentration measurement Jolly et al. (2013). As the analysis is based on direct comparison, the standards of similar matrices were used for the construction of the calibration curve in order to avoid the matrix effect. Three lab-synthesized cellulose-based multi element standards, five plant standards (Apple Leaf/NIST 1516, Spinach/NIST 1570a, Orchard Leaf/ NIST 1571, Tomato Leaf/NIST 1573a, Peach Leaf/NIST
1574) and three fish standards (Tuna-1, Tuna-2, Tuna-3) were used for the construction of calibration curves for carrying out elemental analysis in river water, plant and fish samples respectively. The calibration curve for each element was constructed based on the K X-ray and L Xray intensities calculated for the respective elements present in standard samples. The curves were constructed by plotting the sensitivities of the elements as a function of their atomic number. The validation of calibration curves constructed for elements present in the standards were checked through analysis of standard reference materials (Tuna fish for fish sample and Spinach for vegetable samples). The results obtained for elements of interest and certified values for corresponding elements are shown in the Table 1 . All results in respect of certified known values were found to vary within the acceptable range of error. 
Table 1 Comparison between present results and the certified values of standard reference materials $\left(\mathrm{mg} \mathrm{kg}^{-1}\right)$

\begin{tabular}{|c|c|c|c|c|c|c|}
\hline \multirow[t]{2}{*}{ Elements } & \multicolumn{3}{|l|}{ Tuna Fish } & \multicolumn{3}{|l|}{ Spinach } \\
\hline & Results Obtained & Certified Values & Error & Results Obtained & Certified Values & Error \\
\hline$\overline{\mathrm{K}}$ & - & - & - & 27729 & 29030 & 2.26 \\
\hline $\mathrm{Ca}$ & 9119 & 9640 & 5.41 & 14483 & 15270 & 4.92 \\
\hline $\mathrm{Cr}$ & - & - & - & - & - & - \\
\hline $\mathrm{Mn}$ & 2181 & 2140 & -1.92 & 69.33 & 75.90 & 0.76 \\
\hline $\mathrm{Fe}$ & 39341 & 43200 & 8.93 & - & - & - \\
\hline $\mathrm{Ni}$ & 8.44 & 8.00 & -5.50 & - & - & - \\
\hline $\mathrm{Cu}$ & 3405 & 3420 & 0.44 & 13.30 & 12.20 & -8.98 \\
\hline $\mathrm{Zn}$ & 4197 & 4180 & -0.41 & - & - & - \\
\hline As & 1420 & 1540 & 7.79 & 0.035 & 0.038 & 9.21 \\
\hline $\mathrm{Se}$ & 1.05 & 1.00 & -4.50 & 0.053 & 0.050 & 6.00 \\
\hline $\mathrm{Pb}$ & 5443 & 5520 & 1.39 & - & - & - \\
\hline
\end{tabular}

\section{Statistical analysis}

To assess the contamination level of heavy metals, mean, median, minimum, maximum, and standard deviation of water, fish and vegetable samples were performed using Microsoft Excel (version 2007).

\section{Data analysis}

\section{Metal Pollution Index (MPI)}

Metal pollution index (MPI) was computed to determine overall trace elements concentrations in different foodstuff analysed. This index was obtained by calculating the geometrical mean of concentrations of all the metals in different foodstuff (Ureso et al. 1997)

$$
\operatorname{MPI}\left(\mu \mathrm{g} \cdot \mathrm{g}^{-1}\right)=\left(\mathrm{Cf}_{1} \times \mathrm{Cf}_{2} \times \ldots \times \mathrm{Cf}_{\mathrm{n}}\right)^{1 / \mathrm{n}}
$$

Where $\mathrm{Cf}_{\mathrm{n}}=$ concentration of metal in $\mathrm{n}$ in the sample.

\section{Health Risk Index (HRI)}

The health risk index was calculated as the ratio of estimated exposure of test vegetables and fishes and oral reference dose (Cui et al. 2004). Oral reference doses were $4 \times 10^{-2}$ and $0.3 \mathrm{mg} \mathrm{kg}^{-1}$ day $^{-1}$ for $\mathrm{Cu}$ and $\mathrm{Zn}$ respectively (USEPA 1989); 10-60 and 0.5-5.0 $\mathrm{mg} \mathrm{kg}^{-1}$ day $^{-1}$ for Fe and Mn respectively (Friberg et al. 1984) and $3.01 \mathrm{mg} \mathrm{kg}^{-1}$ day $^{-1}$ for Co (Food and Nutritional Board 2004). In the present study the maximum limit for $\mathrm{Mn}$ and Fe for oral reference dose is considered for HRI calculation. Estimated exposure is obtained by dividing daily intake of heavy metals by their safe limit. An index more than 1 is considered as not safe for human health (USEPA 2002).

Daily intake was calculated by the following equation

Daily intake of metal $(\mathrm{DIM})=\frac{C_{\text {metal }} \times D_{\text {food intake }}}{B_{\text {average weight }}}$

Where, $\mathrm{C}_{\text {metal, }} \mathrm{D}_{\text {food intake, and }} \mathrm{B}_{\text {average weight }}$ represent the heavy metal concentrations in foodstuff $\left(\mu \mathrm{g} \mathrm{g}^{-1}\right)$, daily intake of foodstuff and average body weight, respectively. According to the food consumption, survey by Alam et al. (2003) and Kennedy et al. (2001), Bangladeshi people per person per day consumes vegetable: $130 \mathrm{~g}$ and fish: $24 \mathrm{~g}$ The average body weight $\left(\mathrm{B}_{\text {average weight }}\right)$ was taken as $70 \mathrm{~kg}$ for adults according to WHO 1993.

\section{Result and discussions}

\section{Heavy metal concentration in Buriganga river water}

In contaminated water, the concentration of $\mathrm{Fe}$ was found highest $(31.091 \mathrm{mg} / \mathrm{l})$ and ranged from 20.683 to $39.313 \mathrm{mg} / \mathrm{l}$ which was much higher than the range 4.13 to $5.53 \mathrm{mg} / \mathrm{l}$, reported by Ahmad and Goni (2010) and lowest concentration was found for Co $(0.014 \mathrm{mg} / \mathrm{l})$. Copper concentration ranged from 0.025 to $0.081 \mathrm{mg} / \mathrm{l}$, which was lower than the values $(0.07-6.30 \mathrm{mg} / \mathrm{l})$ reported by Gupta et al. (2008). Maximum Zn concentration in Buriganga river water was $0.427 \mathrm{mg} / \mathrm{l}$. Mn concentration was varied from $<0.74$ to $1.56 \mathrm{mg} / \mathrm{l}$ which was higher than the values (0.031-0.017 $\mathrm{mg} / \mathrm{l})$ reported by Samir et al. (2008). Co concentration was varied from 0.005 to $0.019 \mathrm{mg} / \mathrm{l}$ which was lower than the values (8.08-3.68 $\mathrm{mg} / \mathrm{l})$ reported by Muwanga and Barifaijo (2006). $\mathrm{Zn}$ concentration was varied from 0.167 to $0.427 \mathrm{mg} / \mathrm{l}$, which was higher than the values $(0.135$ -

Table 2 Heavy metal concentration ( $\mathrm{mg} / \mathrm{l}$ ) in Buriganga river water

\begin{tabular}{lllllll}
\hline Metals & Safe limit $^{\mathbf{a}}$ & Mean & Median & Max & Min & S.D \\
\hline $\mathrm{Cu}$ & 0.20 & 0.058 & 0.067 & 0.081 & 0.025 & 0.022 \\
$\mathrm{Co}$ & 0.05 & 0.014 & 0.016 & 0.019 & 0.005 & 0.005 \\
$\mathrm{Fe}$ & 5 & 31.091 & 34.330 & 39.313 & 20.683 & 7.885 \\
$\mathrm{Zn}$ & 2 & 0.234 & 0.187 & 0.427 & 0.167 & 0.109 \\
$\mathrm{Mn}$ & 0.2 & 1.560 & 1.56 & 1.56 & $<0.74$ & 0.698 \\
\hline
\end{tabular}

${ }^{a}$ safe limit of toxic heavy metals in irrigation water for agricultural purpose (Pescod 1992). 
$0.111 \mathrm{mg} / \mathrm{l})$ reported, by Muiruri et al. (2013). The mean concentration (mg/l) of five heavy metals $\mathrm{Cu}, \mathrm{Co}, \mathrm{Fe}, \mathrm{Zn}$ and $\mathrm{Mn}$ in water samples was 0.058, 0.014, 31.091, 0.234 and 1.560 respectively (Table 2 ) and according to Pescod (1992) all the metals are within the safe limit for water to be used in irrigation except Fe and Mn. In a study, Gerbrekidan et al. (2013) also found the concentration of heavy metals $(\mathrm{Cu}, \mathrm{Zn}, \mathrm{Fe}, \mathrm{Mn}, \mathrm{Cr}, \mathrm{Cd}, \mathrm{Ni}, \mathrm{Co}$ and $\mathrm{Pb}$ ) in the water of Gifel River near Shaba Tannery, Tigray, Northern Ethiopia, were lower than the permissible limit allowed for irrigation water. The higher standard deviation observed for heavy metals $\mathrm{Cu}, \mathrm{Fe}, \mathrm{Zn}$ and $\mathrm{Mn}$ in river water which may be due to the ununiform distribution of the respective metals from effluent of various industries. Sharma et al. (2006) also observed a similar trend in the wastewater of Varanasi, India. The data obtained for heavy metals in water from the present study varied more or less regularly with the findings of the other authors (Khan et al. 1998; Al-Nakshabandi et al. 1997). This variation might be ascribed to a variety of industries discharging their treated and/or untreated waste water in to the Buriganga river .hence the concentration of heavy metals in industrial effluents depends on the process of product manufacturing and raw materials used in the industries (Sharma et al. 2006).

\section{Heavy metal concentration in vegetables}

Alam et al. (2003) reported, the average per capita consumption of leafy and non-leafy vegetables is $130 \mathrm{~g}$ person $^{-1}$ day $^{-1}$ in Bangladesh, whis is considerably less than the recommended amounts of $200 \mathrm{~g} \mathrm{person}^{-1}$ day $^{-1}$ from nutritional point of view (Hasan and Ahmad 2000). The range and mean concentration of heavy metal (mg/ $\mathrm{kg}$ dry weight) in edible parts of vegetables grown in the adjacent area of Hazaribag industrial area, Dhaka, Bangladesh are shown in Table 3. In leafy vegetable (Spinach), the $\mathrm{Cu}$ concentration ranged from 3.58 to $6.72 \mathrm{mg} / \mathrm{kg}$ which was higher than the value reported in Tehran, Iran ( 0.13 to $0.37 \mathrm{mg} / \mathrm{kg}$ ) by Delbari and Kulkarni (2013) but lower than the value (15.9-17.4 mg/kg) reported by Arora et al. (2008). In stem Amaranth, mean $\mathrm{Cu}$ concentration was $8.12 \mathrm{mg} / \mathrm{kg}$, which was higher than the value $4.87 \mathrm{mg} / \mathrm{kg}$ reported by Jolly et al. (2013). In radish $\mathrm{Cu}$ concentration ranged 3.58 to $4.32 \mathrm{mg} / \mathrm{kg}$ which was higher than the value $(0.346-0.389 \mathrm{mg} / \mathrm{kg}) \mathrm{re}-$ ported by Farooq et al. (2008). The higher $\mathrm{Cu}$ levels in the studied vegetables may be due to the elevated uptake of the heavy metals by plants grown in adjacent area of Hazaribag industrial region of Bangladesh. Concentration of Co was varied from 0.53 to $1.44 \mathrm{mg} / \mathrm{kg}$ and found in the order of Stem Amaranth $>$ Spinach $>$ Radish. In the present study, the variation of Co concentration in vegetables was strongly supported by the findings $(1.03-1.57 \mathrm{mg} / \mathrm{kg}$ ) of Naser et al. (2011). Mean Fe
Table 3 Heavy metal concentration ( $\mathrm{mg} / \mathrm{kg}$ dry weight) in vegetables grown in and around Hazaribag tannery industrial region, Dhaka, Bangladesh

\begin{tabular}{llllll}
\hline Elements & $\begin{array}{l}\text { Stem Amaranth } \\
(\mathbf{n}=13)\end{array}$ & $\begin{array}{l}\text { Radish } \\
(\mathbf{n}=\mathbf{1 0})\end{array}$ & $\begin{array}{l}\text { Spinach } \\
(\mathbf{n = 8 )}\end{array}$ & $\begin{array}{l}\text { Safe } \\
\text { limit }^{\mathbf{a}}\end{array}$ & WAV $^{*}$ \\
\hline $\mathrm{Cu}$ & $\begin{array}{l}8.12 \\
(4.40-14.38)\end{array}$ & $\begin{array}{l}4.02 \\
(3.58-4.32)\end{array}$ & $\begin{array}{l}5.64 \\
(3.58-6.72)\end{array}$ & 73 & $5-30$ \\
$\mathrm{Co}$ & 1.44 & 0.53 & 1.36 & 50 & $0.02-1$ \\
& $(0.45-3.16)$ & $(0.36-0.65)$ & $(0.96-1.66)$ & & \\
$\mathrm{Fe}$ & 1375 & 305 & 1186 & 425 & - \\
& $(192-3489)$ & $(180-381)$ & $(904-1345)$ & & \\
$\mathrm{Zn}$ & 24.34 & 13.57 & 78.34 & 100 & $27-150$ \\
& $(0-44.53)$ & $(7.43-23.21)$ & $(44.66-98.53)$ & & \\
$\mathrm{Mn}$ & 29.57 & $<0.63$ & 211.56 & 500 & $30-300$ \\
& $(0-80.15)$ & $(86-299)$ & & & \\
\hline
\end{tabular}

$\mathrm{n}$ : number of samples.

${ }^{a}$ safe limit (joint FAO/WHO food standard programme 2001).

*WAV $=$ World Average Value (Pendias 2000).

concentration varied from 305 to $1375 \mathrm{mg} / \mathrm{kg}$, which was higher than the concentration (111-378 mg/kg), observed in vegetables by Arora et al. (2008). Maximum uptake of Fe was found in Stem Amaranth $(1375 \mathrm{mg} / \mathrm{kg})$, followed by Spinach $(1186 \mathrm{mg} / \mathrm{kg}$ ) and Radish $(305 \mathrm{mg} / \mathrm{kg})$. Ahmad and Goni (2010) also reported a higher Fe concentration in vegetables. The highest concentration of $\mathrm{Zn}$ was found in Spinach $(78.34 \mathrm{mg} / \mathrm{kg}$ ) followed by Stem Amaranth (24.34 $\mathrm{mg} / \mathrm{kg}$ ) and Radish $(13.57 \mathrm{mg} / \mathrm{kg}$ ) which agreed with the findings of Liu et al. (2005) in the vegetables from Beijing, China (32.01-69.26 mg/kg) but substantially lower (3.00-171.03 $\mathrm{mg} / \mathrm{kg}$ ) than the vegetables from Titagarh, West Bengla, India (Gupta et al. 2008); Harare, Zimbabwe (1038-1872 m/kg) (Tandi et al. 2004). The maximum concentration of Mn was exhibited by Spinach $(211.56 \mathrm{mg} / \mathrm{kg})$ followed by Stem Amaranth $(29.57 \mathrm{mg} / \mathrm{kg})$ and Radish $(<0.63 \mathrm{mg} / \mathrm{kg})$. Concentration of $\mathrm{Mn}$ in the studied vegetables was ranged from $<0.63-211.56 \mathrm{mg} / \mathrm{kg}$ which is higher than the values $(11.97-22.09 \mathrm{mg} / \mathrm{kg})$ reported by Ahmad and Goni (2010), (61.86-156.24 mg/kg) reported by Jan et al. (2011). However concentration of metals in all the vegetable analysed were within in the safe limit suggested by FAO/WHO, (2001) except Fe and within the word average value (Pendias and Pendias 2000). The exhibition of spatial and temporal variations of all the heavy metal concentration might be ascribed to the variations in heavy metal sources and the quantity of heavy metals discharged through the effluents and sewage in irrigation water of the study area.

\section{Heavy metal concentration in fishes}

In a study Hossain et al. (2008) showed that according to international standard the average per capita consumption of fish is $49 \mathrm{~g} /$ person/day but he found $24 \mathrm{~g} /$ person/day in Bangladesh. The range and mean concentration of heavy 
metals ( $\mathrm{mg} / \mathrm{kg}$ dry weight) in fishes are presented in Table 4. In fresh water fish MozambiqueTalipia, concentration of $\mathrm{Cu}$ ranged from 2.92 to $3.24 \mathrm{mg} / \mathrm{kg}$ which was higher than the value reported in Malaysia (0.27-0.35 mg/ $\mathrm{kg}$ ) (Mokhtar et al. 2009) but lower than the value (4.035.57) reported by Ahmad et al. (2010). In Tatina, mean $\mathrm{Cu}$ concentration was $3.15 \mathrm{mg} / \mathrm{kg}$, which was lower than the value $5.09 \mathrm{mg} / \mathrm{kg}$ reported by Ahmad et al. (2010). In Spotted snakehead mean $\mathrm{Cu}$ concentration was $2.84 \mathrm{mg} /$ $\mathrm{kg}$, which was lower than the value $5.27 \mathrm{mg} / \mathrm{kg}$ reported Ahmad et al. (2010). Concentration of Co varied from 8.17 to $9.09 \mathrm{mg} / \mathrm{kg}$ and found in the order of Spotted snakehead $>$ Tatina $>$ MozambiqueTalipia. Mean Fe concentration varied from 83.48 to $217.49 \mathrm{mg} / \mathrm{kg}$ which was higher than the concentration $(0.3-0.35 \mathrm{mg} / \mathrm{kg}$ ) observed in fishes in Aba River, Nigeria by Ubalua et al. (2007). Fe concentration (194-235 mg/kg) in Mozambique Talipia was higher than the value reported in Asa River, Ilorin, Nigeria (2.95-8.59 mg/kg) (Eletta et al. 2003). Concentration of $\mathrm{Fe}$ in fish samples were found in the order of MozambiqueTalipia $>$ Tatina $>$ Spotted snakehead. The highest concentration of $\mathrm{Zn}$ was found in Tatina (30.12 mg/kg) followed by Spotted snakehead $(24.70 \mathrm{mg} /$ $\mathrm{kg}$ ) and MozambiqueTalipia $(24.52 \mathrm{mg} / \mathrm{kg})$. Concentration of $\mathrm{Zn}(24.52-30.122 \mathrm{mg} / \mathrm{kg})$ in the studied fishes were higher than the value reported in Aba river, Nigeria (1.5$2.5 \mathrm{mg} / \mathrm{kg}$ ) (Ubalua et al. 2007), but substantially lower $(9.8-1226.40 \mathrm{mg} / \mathrm{kg})$ than the concentrations in fresh water fishes of northern delta lakes, Egypt (Saeed and Shaker 2008). The maximum concentration of Mn was exhibited by Spotted snakehead $(11.75 \mathrm{mg} / \mathrm{kg})$ followed by MozambiqueTalipia $(10.35 \mathrm{mg} / \mathrm{kg})$ and Tatina $(6.35 \mathrm{mg} /$ $\mathrm{kg})$. Concentration of $\mathrm{Mn}(6.35-11.75 \mathrm{mg} / \mathrm{kg})$ in fishes were higher than the values $(0.18-0.22 \mathrm{mg} / \mathrm{kg})$ reported by Ubalua et al. (2007) but lower than the value reported by Muiruri et al. (2013) in Athi river, Nigeria (147.72$149.7 \mathrm{mg} / \mathrm{kg}$ ). In the present study $\mathrm{Cu}, \mathrm{Zn}, \mathrm{Fe}$

Table 4 Heavy metal concentration $(\mathrm{mg} / \mathrm{kg})$ in Fishes cultured nearby the area of tannery complex in the river Buriganga

\begin{tabular}{lllll}
\hline Metals & $\begin{array}{l}\text { Spotted snakehead } \\
(\mathbf{n}=\mathbf{9})\end{array}$ & $\begin{array}{l}\text { Tatina } \\
(\mathbf{n}=\mathbf{9})\end{array}$ & $\begin{array}{l}\text { MozambiqueTalipia } \\
(\mathbf{n = 9 )}\end{array}$ & $\begin{array}{l}\text { Safe } \\
\text { limit }\end{array}$ \\
\hline $\mathrm{Cu}$ & 2.84 & 3.15 & 3.05 & 30 \\
& $(2.77-2.93)$ & $(3.02-3.28)$ & $(2.92-3.24)$ & \\
$\mathrm{Co}$ & 9.09 & 9.04 & 8.17 & - \\
& $(9.01-9.14)$ & $(9-9.08)$ & $(7.96-8.44)$ & \\
$\mathrm{Fe}$ & 83.48 & 93.53 & 217.49 & 100 \\
& $(83.15-83.89)$ & $(93.25-93.96)$ & $(194-235)$ & \\
$\mathrm{Zn}$ & 24.70 & 30.12 & 24.52 & 100 \\
& $(24.42-24.98)$ & $(3.02-3.28)$ & $(24.37-24.64)$ & 1 \\
$\mathrm{Mn}$ & 11.75 & 6.35 & 10.35 & \\
& $(7.74-16.27)$ & $(6.28-6.43)$ & $(10.03-10.75)$ & \\
\hline
\end{tabular}

$\mathrm{n}$ : number of samples.

Safe limit: WHO (1989).

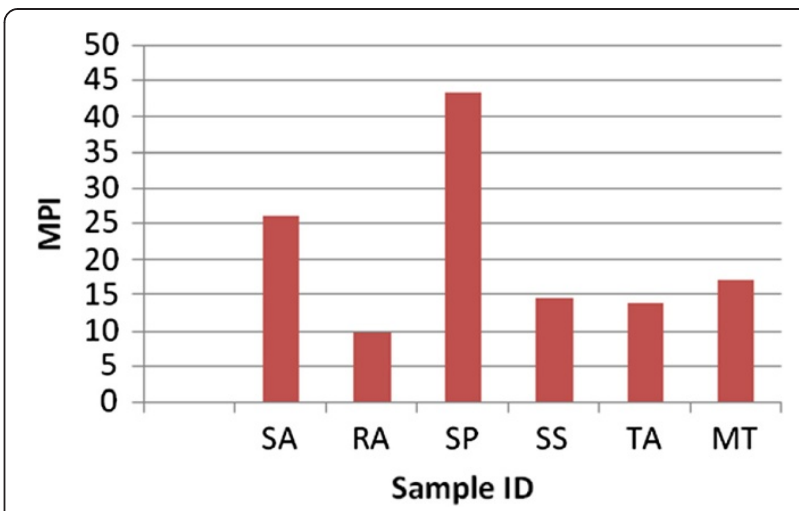

Figure 2 Metal pollution indexes in different foodstuffs analysed. SA=Stem Amaranth; RA=Radish; SP=Spinach; SS= Spotted snakehead; $\mathrm{TA}=$ Tatina; MT= Mozambique Talipia.

Concentration in fishes was within the safe limit of WHO except Mn. The exhibition of spatial and temporal variations of all the heavy metal concentration might be ascribed to the variations in heavy metal sources and the quantity of heavy metals discharged through the effluents and sewage in Buriganga River. Although metal concentration depends on the fish's uptake ability, accumulation ability, fish age, species etc.

\section{Metal pollution index}

Metal pollution index (MPI) is suggested to be a reliable and precise method for metal pollution monitoring of wastewater irrigation areas (Ureso et al. 1997). Among different vegetables and fishes metal pollution index (MPI) as shown in Figure 2 followed a decreasing sequence of Spinach $>$ Stem Amaranth $>$ Mozambique Talipia $>$ Spotted snakehead $>$ Tatina $>$ Radish. Leafy vegetables are found to contain higher MPI value than fishes which are may be due to the uptake of higher amount of heavy metal available from polluted soil. This value also agrees with the findings of Singh et al. (2010) of waste water irrigated site in north east Varanasi and the sequences was as Spinach $>$ Lady's Finger $>$ Tomato $>$ Brinjal $>$ Radish. However higher MPI in Spinach, Stem

Table 5 Health risk index (HRI) of heavy metals via intake if foodstuffs from the adjacent area of Hazaribag

\begin{tabular}{llllll}
\hline Foodstuffs & HRI & & & & \\
\cline { 2 - 6 } & $\mathbf{C u}$ & $\mathbf{C o}$ & $\mathbf{F e}$ & $\mathbf{Z n}$ & $\mathbf{M n}$ \\
\hline Stem Amaranth & 0.38 & $8.88 \mathrm{E}-3$ & 0.04 & 1.13 & $1.09 \mathrm{E}-1$ \\
Radish & 0.19 & $3.27 \mathrm{E}-3$ & $9.44 \mathrm{E}-2$ & 0.08 & 0 \\
Spinach & 0.26 & $8.39 \mathrm{E}-3$ & 0.04 & 0.48 & 0.08 \\
Spotted snakehead & 0.24 & $1.03 \mathrm{E}-2$ & $4.77 \mathrm{E}-2$ & 2.82 & $8.05 \mathrm{E}-2$ \\
Tatina & 0.27 & $1.21 \mathrm{E}-2$ & $5.35 \mathrm{E}-3$ & 0.36 & $4.35 \mathrm{E}-2$ \\
MozambiqueTalipia & 0.26 & $9.31 \mathrm{E}-3$ & $1.24 \mathrm{E}-2$ & 0.28 & $7.10 \mathrm{E}-3$ \\
\hline
\end{tabular}


Amaranth and MozambiqueTalipia suggested that this foodstuff might cause human health risk due to higher accumulation of heavy metal in edible portion.

\section{Health risk assessment}

The health risk assessment associated with heavy metal $(\mathrm{Cu}, \mathrm{Co}, \mathrm{Fe}, \mathrm{Zn}, \mathrm{Mn})$ in locally grown vegetables and fishes of Buriganga River, estimated exposure and risk index were calculated (Table 5). Health risk index was found bellow one (1) in all varieties of vegetables, and fishes for all the measured elements except $\mathrm{Zn}$. In a study Singh et al. (2010) reported $\mathrm{Cu}, \mathrm{Zn}$ and $\mathrm{Cr}$ were not found to cause any risk to the people by consuming vegetables and cereals grown in the area around Dinapur Sewage treatment plant, India. For $\mathrm{Zn}$ it was higher in Stem Amaranth and Spotted Snakehead and hence can pose negative impact on human health those who consumes. On the other hand HRI value lower than 1 for other elements in all varieties of vegetables and fishes may be due to take lower amounts in diet, which consequently decreased the health risk index.

\section{Conclusion}

Irrigation of agricultural land and fish culturing with treated and untreated wastewater led to the accumulation of heavy metals in vegetables and fishes. Variations in the heavy metal concentrations in the studied vegetables and fishes reflect the difference in uptake capabilities and their further translocation to the edible portion of plants and fishes. The mean concentration of heavy metals in water was lower than the safe limit except Fe and $\mathrm{Mn}$. All the vegetables containing heavy metals lower than recommended tolerable levels proposed by FAO/WHO (2001) except Fe and Co and for fishes it is lower than the permissible level set by WHO (1989) except Mn. The metal pollution index, for all varieties of vegetables and fishes are quite high. Consumption of foodstuff with elevated levels of heavy metals may lead to high level of accumulation in the body causing different disease like thalassemia, dermatitis, brain and kidney damage and cancer.

The level of heavy metals (HMs) found in different sources in the present study was compared with the prescribed safe limit provided by WHO (1989) and (2001), WHO (Pescod 1992), World average value (2000). In the present study fish and vegetable samples from uncontaminated area were not analysed but concentrations of metal in fish and vegetables found are compared with the results of different similar studies carried out all over the world and also with the safe limit suggested by different organization. Among five heavy metals studied in vegetables and fishes, concentration of Fe was maximum. The MPI (metal pollution index) value for Spinach was very high compared to other vegetables analysed and suggested to take less amount in diet of local people. Health risk index (HIR) for all HMs were less than 1 , which is may be due to the high level of allowable oral reference dose of the respective metal and this indicate no risk. The study suggests that as there is high concentration of heavy metals in water, its long term use caused heavy metal contamination leading to health risk of consumers. Thus, regular monitoring of these toxic heavy metals in water, vegetables and fishes is essential to prevent their excessive build up in food chain.

\section{Competing interests}

The authors declared that there is no conflict of interest.

\section{Authors' contributions}

Sample is collected by FEK. Analysis was carried out by YNJ, FEK, SA and JK. Final manuscript was drafted and edited by YNJ, FEK and GMR. Islam. All authors read and approved the final manuscript.

\section{Acknowledgement}

Highly appreciate the association and cooperation of the stuff member of Chemistry division, Atomic energy centre, Dhaka and Department of food Engineering \& Tea Technology, Shahjalal University of Science and Technology, Sylhet.

\section{Author details}

${ }^{1}$ Department of food Engineering \& Tea Technology, Shahjalal University of Science and Technology, Sylhet, Bangladesh. ${ }^{2}$ Chemistry Division, Atomic Energy Centre, Dhaka, Bangladesh.

Received: 26 December 2013 Accepted: 7 April 2014

Published online: 29 July 2014

\section{References}

Ahmad JU, Goni MA (2010) Heavy metal contamination in water, soil and vegetables of the industrial areas in Dhaka, Bangladesh. Environ Monit Assess 166:347-357

Ahmad MK, Islam S, Rahman S, Haque MR, Islam MM (2010) Heavy metals in water, sediment and some fishes of Buriganga River. Bangladesh Int J Environ Res 4(2):321-332

Alam MGM, Snow ET, Tanaka A (2003) Arsenic and heavy metal concentration of vegetables grown in Samta village, Bangladesh. Sci Total Environ 111:811-815

Al-Nakshabandi GA, Saqqar MM, Shatanawi MR, Faygad M, Al-Horani H (1997) Some environmental problems associated with the use of treated wastewater for irrigation in Jordan. Agric Water Manag 34:81-94

Arora M, Kiran B, Rani A, Rani S, Kaur B, Mittal M (2008) Heavy metal accumulation in vegetables irrigated with water from different sources. Food Chem 111:811-815

Asaduzzaman ATM, Nury SN, Hoque S, Sultana S (2002) Water and soil contamination from tannery waste: potential impact on public health in Hazaribag and surroundings, Dhaka, Bangladesh. Atlas Urban Geol 14:415-444

Azom MR, Mahmud, Yahya KS, Sontu MA, Himon SB (2012) Environmental impact assessment of tanneries: a case study of Hazaribag in Bangladesh. Int J Environ Sci Dev 3(2):152-156

Cui YJ, Zhu YG, Zhai RH, Chen DY, Huang YZ, Qui Y, Liang JZ (2004) Transfer of metals from soil to vegetables in an area near a smelter in Nanning, China. Environ Int 30:785-791

Delbari AS, Kulkarni DK (2013) Determination of heavy metal pollution in vegetables grown along the roadside in Tehran- Iran. Ann Biol Res 4(2):224-233

Eletta OAA, Adekola FA, Omotosho JS (2003) Determination of concentration of heavy metals in two common fish species from ASA River, llorin, Nigeria. Toxicol Environ Chem 85(1-3):7-12

FAO/WHO (2001) Food Standards Program. Codex Alimentarius Commission (FAO/WHO) Food additives and contaminants, Geneva, Switzerland, ALINORM 01/12A, pp 1-289 
Farooq M, Anwar F, Rashid U (2008) Appraisal of heavy metal contents in different vegetables grown in the vicinity of an industrial area. Pak J Bot 40 (5):2099-2106

Food and Nutritional Board (2004) Dietary Reference Intakes [DRIs]. Recommended Intake for Individuals. National Academy of Sciences, Washington, DC: USA

Friberg L, Nordberg GF, Vpuk B (1984) Handbook on the Toxicity of Metals. Elsevier, Nort Holland, Bio Medical Press, Amsterbam

Gebrekidan A, Weldegebriel Y, Hadera A, Vander Bruggen B (2013) Toxicological assessment of heavy metals accumulated in vegetables and fruits grown in Ginfrel River near Sheba tannery, Tigray, Northern Ethiopia. Ecotox Environ Safety 95:171-178

Gupta N, Khan DK, Santra SC (2008) an assessment of heavy metal contamination in vegetables grown in wastewater-irrigated areas of Titagarh, West Bengle, India. B Environ Contam Tox 80:115-118

Hasan N, Ahmad K (2000) Intra-familial distribution of food in rural Bangladesh. Institute of Nutrition and Food Science. University of Dhaka, Bangladesh

Hina B, Rizwani GH, Naseem S (2011) Determination of toxic metals in some herbal drugs through atomic absorption spectroscopy. PakJPharmSci 24 (3):353-358

Hossain MAR, Nahiduzzaman M, Sayeed MA, Saha D, Azim ME (2008) Fish consumption amongst poor people in Bangladesh: Effects of gender, location and wealth class. Aquaculture News, Bangladesh

Industrial Effluent Quality Criteria (1999) A comparision of Environmental Laws, Bangladesh Gazzette Additional 28, department of Environment (DoE). The Ministry of Environment and Forests, Bangladesh, p 60

Jan FA, Ishaq M, Khan S, Shakirullah M, Asim SM, Ahmad I (2011)

Bioaccumulation of metals in human blood in industrially contaminated area. J Environ Sci 23(12):2069-2077

Jolly YN, Islam A, Akbar S (2013) Transfer of metals from soil to vegetables and possible health health risk assessment. Springerplus 2:385. doi:10,1186/2193-1801-2-385

Kennedy G, Burlingame B, Nguyen VN (2001) Nutritional contribution of rice and impact of biotechnology and biodiversity in rice-consuming countries. Crop and Grassland Service, FAO, Rome, Italy

Khan YSA, Hossain MS, Hossain SMGMA, Halimuzzaman AHM (1998) An environment of trace metals in the GMB Estuary. J Remote Sensing Environ 2:103-113

Khan S, Cao Q, Zheng YM, Huang YZ, Zhu YG (2008) Health risks of heavy metals in contaminated soils and food crops irrigated with wastewater in Beijing, China. Environ Pollut 152:686-692

Liu WH, Zhao JZ, Ouyang ZY, Soderlund L, Liu GH (2005) Impacts of sewage irrigation on heavy metals distribution and contamination. Environ Int 31:805-812

Mingorance MD, Valdes B, Oliva Rossini S (2007) Strategies of heavy metal uptake by plants growing under industrial emissions. Environ Int 33(4):514-520

Mokhtar MB, Aris AZ, Munusamy V, Praveena SM (2009) Assessment level of heavy metals in Penaeus Monodon and Oreochromis Spp in selected aquaculture ponds of high densities development area. Eur J Sci Res 30 (3):348-360

Muchuweti M, Birkett JW, Chinyanga E, Zvauya R, Scrimshaw MD, Lester J (2006) Heavy metal content of vegetables irrigated with mixture of wastewater and sewage sludge in Zimbabwe: Implications for human health. Agric Ecosyst Environ 112:41-48

Muiruri JM, Nyambaka HN, Nawiri MP (2013) Heavy metals in water and tilapia fish from Athi-Galana-Sabaki tributaries, Kenya. Int Food Res J 20(2):891-896

Muwanga A, Barifaijo E (2006) Impact of industrial activities on heavy metal loading and their physic-chemical effects on wetlands of lake Victoria basin (UGANDA). Afr J Sci Technol 7(1):51-63

Naser HM, Sultana S, Mahmud NU, Gomes R, Noor S (2011) Heavy metal levels in vegetables with growth stage and plant species variations. Bangladesh J Agril Res 36(4):563-574

Okunola OJ, Alhassan Y, Yapbella GG, Uzairu A, Tsafe Al, Abechi ES, Apene E (2011) Risk assessment of using mobile phone recharge cards in Nigeria. J Environ Chemistry Ecotox 3(4):80-85

Pendias AK, Pendias H (2000) Trace elements in Soils and Plants. CRC press, FL, United States, pp 10-11

Pescod MB (1992) Wastewater treatment and use in agriculture.FAO irrigation and Drainage paper 47. Food and Agriculture Organization of United Nations, Rome

Saeed S, Shaker MI (2008) Assessment of heavy metals pollution in water and sediments and their effect on Oreochromis niloticus in the Northern Delta Lakes, Egypt. Int Symposium on Tilapia Aquaculture 8:475-490
Sharma RK, Agrawal M, Marshall F (2006) Heavy metal contamination in vegetables grown in wastewater irrigated areas of Varanasi, India. B Environ Contam Tox 77:312-318

Sharma R, Agrawal M, Marshall F (2007) Heavy metal contamination of Soil and Vegetables in suburban areas of Varanasi, India. Ecotoxicol Environ Saf 66:258-266

Singh A, Sharma RK, Agarwal M, Narshal FM (2010) Health risk assessment of heavy metal via dietary intake of foodstuffs from the wastewater irrigated site of a dry tropical area of India. Food Chem Toxicol 48:611-619

Tandi NK, Nyamangara J, Bangira C (2004) Environmental and potential health effects of growing leafy vegetables on soil irrigated using sewage sludge and effluent: a case of Zn and Cu. J Environ Sci Health B 39:461-471

Tripathi RM, Raghunath R, Krishnamoorthy TM (1997) Dietary intake of heavy metals in Bombay City, India. Sci Total Environ 208:149-159

Ubalua AO, Chijioke UC, Ezeronye OU (2007) Determination and assessment of heavy metal content in fish and shellfish in Aba River, Abia State, Nigeria. KMITL Sci Tech J 7(1):16-23

Ureso J, Gonzalez-Regalado E, Gracia I (1997) Trace elements in bivalvemollusks Ruditapes decussates and Ruditapes phillippinarum from Atlantic Coast of Southern Spain. Environ Int 23(3):291-298

US Environmental Protection Agency (US EPA) (1989) Risk Assessment Guidance for Superfund: Human Health Evaluation Manual [part A]: Interim Final. U.S. Environmental Protection agency, Washington, DC, USA [EPA/540/1-89/002]

US Environmental Protection Agency (US EPA) (2002) Region 9, Prelominary Remidation Goals

WHO (1989) Heavy metals-environmental aspects. Environment Health Criteria. No. 85, Geneva, Switzerland

WHO (1993) Evaluation of certain food additives and contaminants in Forty-First report of the joint FAO/WHO expert committee on food additives. WHO, Geneva, Switzerland, WHO technical series, 837

Yoon KP (2003) Construction and characterization of multiple heavy metalresistant Phenol-degrading pseudomonads strains. J Micro Biotech 13 (6):1001-1007

Zhuang P, McBride BB, Xia HP, Liny, Liza (2009) Health risk from heavy metals viz consumption of food crops in vicinity of Dabaoshan mine, South China. Sci Total Environ 407:1551-1561

\section{doi:10.1186/s40550-014-0001-z}

Cite this article as: Khan et al: Contamination status and health risk assessment of trace elements in foodstuffs collected from the Buriganga River embankments, Dhaka, Bangladesh. International Journal of Food

Contamination 2014 1:1.

\section{Submit your manuscript to a SpringerOpen ${ }^{\odot}$ journal and benefit from:}

- Convenient online submission

- Rigorous peer review

- Immediate publication on acceptance

- Open access: articles freely available online

- High visibility within the field

- Retaining the copyright to your article

Submit your next manuscript at springeropen.com 